\title{
BULLETIN of the
}

\section{BUSINESS HISTORICAL SOCIETY}

THE COLE BROTHERS PUMP AND LIGHTNING ROD COMPANY

BY ROBERT W. LOVETT

THE MEMOIR OF A NOTTINGHAM LACE MERCHANT:

WILLIAM CRIPPS, 1798-1884

By J. D. Chambers

INDEX TO BULLETIN AVAILABLE TO MEMBERS OF THE SOCIETY

A NEW BOOK ON ANGLO-AMERICAN TRADE AND FINANCE: A REVIEW

By Charles C. Abbott 


\section{BUSINESS HISTORICAL SOCIETY, INC.}

Organized in 1925 to promote the study

of business enterprise

from an historical point of view

\section{Officers}

John W. Higgins, President

N. S. B. Gras, Vice-President

Allan Fonbes, Treasurer

Philip J. Potter, Assistant Treasurer

Arthur H. Cole, Librarian

Thomas R. Navin

Executive Secretary and Clerk

Elsie H. Bishop

Assistant Executive Secretary
Members of the Council

Charles Francis adams

Thomas C. Cochran

Donald K. David

Allan Forbes

N. S. B. Gras

Charles B. Harding

John W. Higains

JoHN C. KILEY

Henrietta M. Larson

Augustus P. Loring III

Henry L. Shatruck

D. George Sullivan

R. GoRdon WasBon

Wallace B. Donham

Honorary Member

The Society collects business manuscripts, books, and reports, distributes publications, and otherwise promotes research; the Harvard Graduate School of Business Administration furnishes space and also assistance from the members of its faculty and staff. The Harvard Business School Associates receive all the publications of the Society.

\section{BULLETIN OF THE BUSINESS HISTORICAL SOCIETY, INC.}

\section{HenRIETTA M. LaRson Editor}

\section{Eugie H. Bishop Assistant Editor}

Published quarterly and sent free to members of the Society.

For further information concerning the Society or the Bulletin, address The Business Historical Society, Soldiers Field, Boston 63, Massachusetts.

Copyright, 1950, by The Business Historical Society, Inc. 